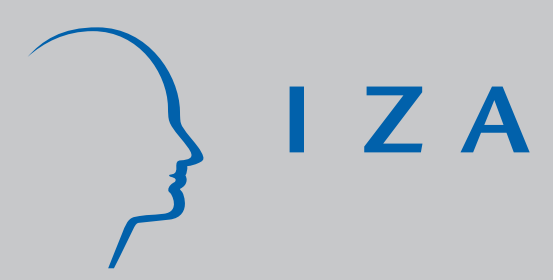

IZA DP No. 5850

The Long-Term Direct and External Effects of Jewish Expulsions in Nazi Germany

Mevlude Akbulut-Yuksel

Mutlu Yuksel

July 2011

Forschungsinstitut

zur Zukunft der Arbeit

Institute for the Study

of Labor 


\title{
The Long-Term Direct and External Effects of Jewish Expulsions in Nazi Germany
}

\author{
Mevlude Akbulut-Yuksel \\ Dalhousie University, \\ HICN and IZA \\ Mutlu Yuksel \\ Dalhousie University \\ and IZA
}
Discussion Paper No. 5850
July 2011
IZA
P.O. Box 7240
53072 Bonn
Germany

Phone: +49-228-3894-0

Fax: +49-228-3894-180

E-mail: iza@iza.org

Any opinions expressed here are those of the author(s) and not those of IZA. Research published in this series may include views on policy, but the institute itself takes no institutional policy positions.

The Institute for the Study of Labor (IZA) in Bonn is a local and virtual international research center and a place of communication between science, politics and business. IZA is an independent nonprofit organization supported by Deutsche Post Foundation. The center is associated with the University of Bonn and offers a stimulating research environment through its international network, workshops and conferences, data service, project support, research visits and doctoral program. IZA engages in (i) original and internationally competitive research in all fields of labor economics, (ii) development of policy concepts, and (iii) dissemination of research results and concepts to the interested public.

IZA Discussion Papers often represent preliminary work and are circulated to encourage discussion. Citation of such a paper should account for its provisional character. A revised version may be available directly from the author. 


\section{ABSTRACT \\ The Long-Term Direct and External Effects of Jewish Expulsions in Nazi Germany}

This paper provides causal evidence on long-term consequences of Jewish expulsions in Nazi Germany on the educational attainment and political outcomes of German children. We combine a unique city-level dataset on the fraction of Jewish population residing in Germany before the Nazi Regime with individual survey data from the German Socio-Economic Panel (GSOEP). Our identification strategy exploits the plausibly exogenous city-by-cohort variation in the Jewish population in Germany as a unique quasi-experiment. We find that the persecution of Jewish professionals had significant, long-lasting detrimental effects on the human capital and political development of Germans who were at school-age during the Nazi Regime. First, these children have 0.4 fewer years of schooling on average in adulthood. Second, these children are less likely to go to college or have a graduate degree. Third, they are less likely to have interest in politics as adults. These results survive using alternative samples and specifications, including controlling for Second World War, Nazi and Communist Party support and unemployment effects.

JEL Classification: $\quad$ 121, I12, J24, N34

Keywords: human capital formation, dismissal, Jewish professionals, political development

Corresponding author:

Mevlude Akbulut-Yuksel

Department of Economics

Dalhousie University

6214 University Avenue

Halifax, Nova Scotia B3H $3 J 5$

Canada

E-mail: mevlude@dal.ca

\footnotetext{
* We are especially grateful to Joshua Angrist, Aimee Chin, Barry Chiswick, Carmen Chiswick, Nicola Fuchs-Schundeln, Ira Gang, Daniel Hamermesh, Tarek Hassan, Paul Huber, Chinhui Juhn, Melanie Khamis, Murat Kirdar, Adriana Kugler, Peter Kuhn, Lars Osberg, Andrew Oswald, Gerard van den Berg, Fabian Waldinger, Courtney Ward and Anzelika Zaiceva as well as seminar participants in Georgia Institute of Technology, Sabanci University, Middle East Technical University, TOBB University, IZA; 2010 SOLE, 2010 NEUDC, 2010 HICN Meeting for very useful comments and discussions. The authors bare the sole responsibility for any errors that may remain.
} 


\section{Introduction}

An extensive literature on endogenous economic growth has emphasized the role of human capital as a source of long-run differences in income levels across countries (Klenow and Rodriguez-Clare, 2005; Lucas, 1988). The loss of productive skills due to armed conflicts, ethnic cleansing, natural disasters, diseases and brain drain immigration however seems to have gotten more common in the last few decades (Blatmann and Miguel, 2010; Carrington and Detragiache, 1998; de Walque and Verwimp, 2010). The lack of high-skilled professionals may especially leave children and young adults vulnerable given the age-specific aspect of many human capital investments.

This paper provides causal evidence on long-term consequences of the expulsion and mass murder of high-skilled professionals on children's outcomes. Specifically, we analyze the long-term effects of the Jewish expulsions in Nazi Germany on the German children's educational attainment and political outcomes who were school-aged during the Nazi Regime. The Hitler's Nazi Party passed the "Law for the Restoration of the Professional Civil Service" shortly after they came into power in 1933. This law allowed the Nazi government to purge Jews from civil service, a vast organization in Germany that included school teachers, university professors, judges and many other professionals. With the passage of civil service law, more than 15 percent of university professors, school teachers, doctors and other white-collar professionals who were Jewish were dismissed from their professions (Strauss, 2005; German Statistical Yearbooks). ${ }^{2}$ However, there was a significant variation in the extent of dismissals within Germany.

\footnotetext{
${ }^{2}$ Starting from 1933, many Jewish professionals including Albert Einstein, Gustav Hertz, Erwin Schroedinger, Max Born and twenty past or future Nobel Prize winners, left the country (Evans, 2005). Similarly, German Statistical Yearbooks report that $8.3 \%$ of the school teachers were dismissed by the Nazi government in 1933 .
} 
On the one hand, cities with higher fraction of Jewish population were exposed to a dramatic change in the number of teachers, university professors and other professionals compared to cities with lower fraction of Jews. The magnitude of high-skilled loss depended on the ex ante (1933) fraction of Jewish population residing in German cities. ${ }^{3}$ On the other hand, only individuals who were of school-age during the Nazi Regime would have had their human capital formation affected by the exile of Jewish professionals; the human capital of cohorts born after WWII reconstruction period would not be affected by the dismissal of Jewish professionals (Akbulut-Yuksel, 2009). ${ }^{4}$ This paper therefore uses a difference-in-differences-type strategy where the "treatment" variable is an interaction between city-level Jewish population before the exclusion of Jewish professionals and a dummy variable for being school-aged during the Nazi Regime, and where we always control for city fixed effects and birth year fixed effects. The identifying assumption is that had the expulsion of Jewish population not occurred, the difference in schooling and political outcomes between the affected cohorts and the cohorts born after the postwar reconstruction would have been the same across cities of varying percentage of ex ante Jewish population.

Our analysis combines unique city-level data on the fraction of Jewish population residing in the former West Germany in 1933 and 1946 with individual-level data from the German Socio-Economic Panel (GSOEP), a nationally-representative survey. ${ }^{5}$ Since the systematic persecution of Jews from public life began shortly after the Nazi Party seize the power in 1933, our historical data gives the most accurate information on the fraction of Jews

\footnotetext{
${ }^{3}$ Figure 1 and Figure 2 show that cities with higher ex ante Jewish population had a greater decline both in the number of Science professors and school teachers after the Nazi Party came into power in 1933.

${ }^{4}$ Akbulut-Yuksel (2009) shows that the schools were rebuilt and number of teachers reached the prewar levels in the early 1960s. Therefore as explained in Section 4, we will use individuals born after 1950s as the control group.

${ }^{5}$ The analysis is restricted to former West Germany. West Germany is comprised of 75 German Regional Policy Region (Raumordnungsregionen, hereafter, "ROR" or "city").
} 
residing in Germany before Holocaust. In addition, we compiled unique city-level data on ex ante average income per capita and unemployment rate, population, the share of votes received by Nazi Party (NSDAP) and Communist Party (KPD), the change in the number of teachers and professors and wartime destruction German cities experienced during WWII.

This paper makes several contributions. First, this paper contributes to the broader literature looking at the long-term effects of negative shocks on children's and young adults' outcomes. Specifically, we rigorously quantify the unintended long-term consequences of systematic persecution and mass murder of Jewish population in Nazi Germany on German children's human capital formation and political development. Second, our study adds to the growing literature looking at the long-term economic and political legacies of Holocaust (Acemoglu, Hassan and Robinson, 2010; Grosfeld, Rodnyansky and Zhuravskaya, 2011; Waldinger, 2011; 2010). However, in contrast to other studies, in this study, we analyze the micro-level effects of Holocaust and focus on all children and young adults at large. We combine the city-level data on the fraction of Jews before the expulsions with individual-level survey data, which allows us to control for individual and family background characteristics in the analysis of long-term consequences of Holocaust. Third, this paper may be relevant on the general question of how "high skilled emigration" impacts the human capital accumulation and political outcomes in the source countries. Blattman and Miguel (2010) point out that the rigorous research on long-term effects of war-related high skilled emigration is very limited. Therefore, it is critical to understand the long-run effects of loss of high-skilled professionals and the mechanisms through which it impacts children and young adults to devise policies and programs. 
We find that Holocaust had enduring detrimental effects on German children's education and political outcomes. First, children who were school-aged during the Nazi Regime had 0.4 fewer years of schooling on average in adulthood. Second, these children were less likely to go to a technical school and university or have a graduate degree. Third, they are less likely to have interest in politics as adults. An important channel for the effects of Holocaust on educational attainment appears to be the dismissal and exile of university professors and school teachers. Given the sizable impact on political outcomes, it is likely that size of the middle class and change in the social structure are important mechanisms behind the estimated effects.

During the time period we focus on our paper, Germany also experienced other major political and economic events including the Nazi Regime, WWII and Great Depression. It is possible that German cities might have been differentially impacted by these historical events, which may raise potential concerns on the interpretation of our findings. We formally test whether our results are confounded by these events in Section 6. We find that the long-term negative effects of the Jewish expulsions on German children's outcomes remain to be economically and statistically significant even after we account for these other major political and economic events Germany had experienced.

The remainder of the paper is organized as follows. Section 2 reviews the related literature. Section 3 provides a brief background of the expulsion of Jewish professionals during the Nazi Regime. Section 4 discusses the identification strategy. Section 5 describes the citylevel historical data and individual-level survey data used in the analysis. Section 6 presents the main results, extensions and robustness checks. Section 7 concludes. 


\section{Literature Review}

This paper is related to the broader literature looking at the long-term effects of negative shocks such as armed conflicts, natural disasters, famines, diseases and macroeconomic crisis on children's human capital formation and political development. A set of studies has shown that exposure to armed conflicts and wartime destruction had long-lasting, detrimental effects on school-aged children's human capital formation (Akbulut-Yuksel, 2009; Akresh and de Walque, 2008; Shemyakina, 2006). Several prior studies have also analyzed the effects of HIV epidemic in Africa on children's educational attainment. These studies find that HIV/AIDS epidemic substantially hinders the human capital accumulation of children in South Africa and subSaharan Africa (Case, Paxson and Ableidinger, 2004; Case and Ardington, 2006; Evans and Miguel, 2007; Fortson, 2011). In addition, Bellows and Miguel (2009; 2006) in Sierra Leone and Blattman (2009) in Uganda find that political participation after civil conflict is greater, and that community networks are more extensive, in areas that have experienced violence.

Our study contributes to the small but growing literature which analyzes the long-term economic and political legacies of Holocaust. Using the variation in the percentage of pre-war Jewish population and Nazi occupation during WWII in Russia, a recent paper by Acemoglu, Hassan and Robinson (2010) estimates the long-term macro-level effects of Holocaust on economic and political development in Russian cities and regions. They show that in the cities and regions with higher pre-war Jewish population, German occupation led to a lower post-war growth, GDP per capita and average wages. In addition, German occupation increased the support for the Communist candidates in these cities since the collapse of the Soviet Union. They suggest that the change in the social structure, in particular the size of the middle class is responsible for estimated long-term effects of Holocaust. Grosfeld, Rodnyansky and 
Zhuravskaya (2011) provide further evidence from Eastern Europe on long-term macro-level legacies of Holocaust. As a source of exogenous variation in prewar Jewish population in Eastern Europe, they use the "Pale of Settlement", which was determined at the time of the Russian Empire. They find that cities in Pale settlement have a stronger support for socialist antimarket parties, lower rates of entrepreneurship and higher levels of trust today. They also show that the Pale has no long-term effects on average consumption, income and education levels. They propose that the interaction with the Jewish community in the Pale intensified the trust and anti-market culture among non-Jewish population; thus this serves as a main mechanism behind their findings.

This study is related to two recent studies by Waldinger $(2011 ; 2010)$, who examines the effects of the dismissal of Jewish professors in Nazi Germany on productivity of fellow German scientists and $\mathrm{PhD}$ students. As a source of identification in peer and university quality, he uses the dismissal of Science professors by the Nazi government. Focusing on German scientist in Physics, Chemistry and Mathematics, Waldinger (2011) finds that the productivity of peer scientists in the departments of dismissed Jewish professors remained virtually unchanged after the dismissals. Waldinger (2010) however shows that in Mathematics departments, dismissal of Jewish professors caused a decline in university quality, which has negative long-term consequences for $\mathrm{PhD}$ students graduated from these departments. He finds that these $\mathrm{PhD}$ students are less likely to publish their dissertation in top journals, become full professors and have positive lifetime citations. The persecution and mass murder of Jews in all professions and consequent loss of human capital in Germany at large is likely to have more pervasive long-term effects beyond German researchers and $\mathrm{PhD}$ students in Science. In our study, we estimate the long-term legacies of systematic persecution of Jewish population in Nazi Germany on all 
German children's and young adults' human capital and political development; therefore our analysis takes the potential spillover effects arising from loss of human capital at large into account.

This study also adds to the literature looking at the association between the brain drain emigration and economic and political development of source countries. This strand of literature provides somewhat mixed evidence on the short-term and long-term consequences of brain drain on source countries. On the one hand, several studies suggest that brain drain has adverse effects on those left behind even when the positive feedback effects such as remittances, return migration with additional skills acquired abroad and creation of scientific and business networks are taken into account (McKenzie, Gibson and Stillman, 2011; McKenzie and Rapoport, 2010; Klenow and Rodriguez-Clare, 2005). On the other hand, recent studies by Beine, Docquier and Rapoport $(2008 ; 2001)$ provide evidence suggesting that the probability of future migration fosters the human capital formation in the source countries. These studies show that countries with relatively lower human capital and low skilled migration rate are likely to benefit the most from the high-skilled emigration.

\section{Background on Dismissal of Jewish Professionals during the Nazi Regime}

The 1933 census established that there were 525,000 Jews in West Germany at that time, composing 1.13 percent of the country's population. ${ }^{6}$ Even though, Jews were approximately 1 percent of the German population, they had mostly been remarkably successful in German society and culture since their emancipation from legal restrictions in the course of the nineteen century (Evans, 2005). The Jewish community gained in visibility by gradually concentrating in

\footnotetext{
${ }^{6}$ The corresponding percentage of Jewish population in Russia in the recent paper by Acemoglu, Hassan and Robinson (2010) is 0.87 for cities and 0.55 for oblasts (administrative units) in Russia.
} 
the large cities. ${ }^{7}$ Moreover, Jews tended to be concentrated in certain professions and occupations. In some of these professions the ratio of Jews was several times that of the population at large. A substantial number of Jews were in academe or practiced professions such as medicine, teaching, law, journalism, banking and finance.

The systematic persecution of the Jews began shortly after the Hitler's Nazi Party came into power in 1933. Two turning points took place in the first few months of the Nazi regime: the boycott of Jewish stores on April 1, 1933, and the exclusion of Jews from the civil service through the "Law for the Restoration of the Professional Civil Service" of April 7 (Evans, 2005). This law allowed Nazi government to purge Jews from civil service, a vast organization in Germany that included school teachers, university professors, judges and many other professionals that were not government-controlled in other countries. In May 1933, it was amended to include supplemental regulations for other status groups, and the extensions of the term "civil service" to include the postal service, railroads, communal health insurance systems, professional associations, unemployment and salaried employees' insurance, miners' guilds, trade guilds and chambers of commerce followed.

As a result of "Law for the Restoration of the Professional Civil Service", a growing number of Jewish teacher were forced to leave their jobs in the general school system. For instance, in Baden, the minister of education had ordered leaves of absence on April 5, 1933, for all "members of the Jewish race" for the purpose of "maintaining security and order". With the passage of civil service law, some of those given leave of absence were permanently dismissed. Those Jewish teachers, who were not fired in April 1933, were compulsorily pensioned off in

\footnotetext{
${ }^{7}$ Two-thirds of Jews were concentrated in cities over 100,000 inhabitants. The remaining third lived in settlements ranging from middle-sized cities down to villages (Kaplan, 2005).
} 
1935; two years after Jews and "half-Jews" were formally banned from teaching in non-Jewish schools.

With the civil service law, Jewish professors in all fields were also dismissed. According to an estimate of social historian Herbert Strauss (1983), approximately 15 percent $(1,100$ to 1,500$)$ of university professors of all categories were dismissed and forced to emigrate starting from 1933. When non-university research scientists and scholars who had begun but not completed their training at the time of emigration are included, this figure becomes approximately 2,000. The number was even higher in medicine. Professors of medicine made up roughly a third of all university faculty members by 1935, and during the Nazi Regime, 59 percent of university professors were drawn from the medical profession (Evans, 2005).

Further legislation in 1933 sharply curtailed "Jewish activity" in the medical and legal professions. In July 1933, Jewish doctors lost their patients with substitute health insurance schemes, and private insurance companies reimbursed the fees of Jewish doctors only for their Jewish patients. In 1938, all Jewish doctors lost their medical licenses, and Jewish lawyers lost their admission to the bar. Removal of Jewish doctors from the profession created a large number of vacancies for Aryan graduates to fill.

Starting from April 1933, German law also restricted the number of Jewish students at German schools and universities. Additionally, the hostility of the Nazi Students' League drove most Jewish students out of universities within a short space of time, so that only 590 were left in the autumn semester of 1933 compared to 3,950 in the summer semester of the previous year. In a similar vein, the hostility of Nazi teachers and increasing Hitler Youth activists in the schools had a powerful effect in driving Jewish children and young adults out. 
The foregoing discussion on the historical accounts of Holocaust suggests that the severity of the Holocaust in Germany depended on the fraction of the Jewish population before the expulsions. In our main analysis, we will take the cross-city variation in the percentage of ex ante Jewish population in Nazi Germany as exogenous once we control for city fixed effects.

\section{Identification Strategy}

In this section, we describe our strategy for identifying the causal effect of the dismissal and exile of the Jewish population on the long-term outcomes of German children. This strategy exploits the plausibly exogenous city-cohort variation in the fraction of Jewish population in Nazi Germany. This is a difference-in-differences-type strategy where the "treatment" variable is an interaction between percentage of Jews in German cities in 1933 and a dummy variable for being school-aged during the Nazi Regime. ${ }^{8}$ In particular, the proposed estimate of the average treatment effect is given by $\beta$ in the following baseline city and year of birth fixed effects equation:

$$
\mathrm{Y}_{\text {irt }}=\alpha+\beta\left(\text { JewishFraction }_{r} \times \text { AffectedCohort }_{i t}\right)+\delta_{r}+\gamma_{t}+\pi^{\prime} \mathbf{X}_{\text {irt }}+\varepsilon_{\text {irt }}
$$

where $\mathrm{Y}_{i r t}$ is the outcome of interest for individual $i$ in city $r$ born in year $t$. JewishFraction Is the percentage of Jewish population in 1933 in city $r$. AffectedCohort ${ }_{i t}$ is a dummy variable that takes a value of 1 if individual $i$ was born between 1915 and 1923 and zero otherwise. Individuals born between 1915 and 1923 were 18 and younger when the Nazi government forced

\footnotetext{
${ }^{8}$ This paper provides evidence on the long-term impacts of Jewish expulsions using city-by-cohort variation in ex ante Jewish population within Germany; therefore this approach may yield lower bound estimates for the aggregate nation-wide effects of persecution of Jews.
} 
Jews out of the civil service, independent professions and higher education in $1933 .{ }^{9}$ Thus, their schooling has the potential to be affected by the dismissal of Jewish teachers and professors from public schools and universities. Individuals who attained their education after post-war reconstruction which was completed in late 1950s would not have been impacted by the persecution of Jewish professionals; hence these later birth cohorts are in the control group. ${ }^{10} \delta_{r}$ is city-specific fixed effects, controlling for the fact that cities may be systematically different from each other. $\gamma_{t}$ is the birth year-specific fixed effect, controlling for the likely secular changes across cohorts. Since we will be using a single cross section, this $\gamma_{r}$ accounts for not only cohort but also age effects. $\mathbf{X}_{i r t}$ is a vector of individual characteristics including gender and rural dummies as well as family background characteristics. $\varepsilon_{i r t}$ is a random, idiosyncratic error term. Following Bertrand, Duflo and Mullainathan (2004), the standard errors are clustered by city to account for correlations in outcomes between individuals in the same city over time.

In order to interpret $\beta$ as the effect of Holocaust, we must assume that had the persecution of Jewish population not occurred, the difference in schooling and political outcomes between the affected cohorts and the cohorts born after WWII would have been the same across cities of varying intensity of Jewish population before the Nazi Regime. We assess the plausibility of this assumption below by performing a falsification test/control experiment where we repeat the analysis using only cohorts who were already beyond school age before the expulsions.

\footnotetext{
${ }^{9}$ The estimation results are robust to different cut-offs and birth years. Results are reported in Appendix Table 1 and Appendix Table 2.

${ }^{10}$ As we explain below, we will use individuals born 1951-1960 as the control cohorts. Individuals born 1924-1950 are dropped since they were also exposed to WWII destruction.
} 


\section{Data and Descriptive Statistics}

The measure of ex ante Jewish population we use for our main analysis is from Kessner (1935), who reports the German population statistics from German Population and Occupation Census conducted in 1933. Kessner provides city-level information on the fraction of Jewish population residing in German cities in 1933, which is what we use as a measure of Holocaust. Since the dismissal and emigration of German Jews started after the passage of "Law for the Restoration of the Professional Civil Service" in 1933, we believe that this data gives the most accurate information on the fraction of Jews in Germany during the Nazi Regime. In addition, to assure that our empirical analysis is not sensitive to the choice of Holocaust measure, we compiled city-level information on the fraction of Jewish population residing in German cities in 1946 (Einer, 1949). Using both ex ante and ex post percentage of Jews in German cities, we generate an alternative measure of Holocaust.

In order to assess the distribution of Jews in Nazi Germany and the mechanisms through which the expulsion of Jewish population might have affected German children's long-run outcomes, we gathered unique data from various years of the German Statistical Yearbooks. First, we compiled data on city characteristics including average income per capita and unemployment rate in 1932, area and population size in 1933, the share of votes Nazi Party (NSDAP) and Communist Party (KPD) received in 1932 elections. Second, we assembled cityyear data on the number of teachers and professors; of particular interest is the change in the number of teachers and professors immediately after 1933 because this would have been the change in school inputs available to the affected cohorts. Additionally, we compiled city-level data on physical destruction experienced by German cities during WWII. Kaestner (1949) provides city-level information on the aggregate residential rubble in $m^{3}$ per capita in German 
cities by the end of WWII, which is what we use as a measure of city's overall wartime destruction.

The data on individual and household characteristics come from the confidential version of German Socio-Economic Panel (GSOEP). GSOEP is a household panel survey that is representative for the entire German population residing in private households. It provides a wide range of information on individual and household characteristics as well as parental background and the childhood environment in which one grows up. We restrict the empirical analysis to individuals born between 1915 and 1960. These individuals are 25 and older in 1985; thus it is very likely that they have completed their human capital formation. We dropped individuals born between 1924 and 1950 from the analysis since they were exposed to WWII destruction (Akbulut-Yuksel, 2009).

We consider the Holocaust impacts at the Raumordnungsregionen level ("ROR", or "city"). RORs are analogous to metropolitan statistical areas (MSAs) in the U.S., though, in contrast to MSAs, RORs also encompass rural areas; that is, all of Germany, regardless of urbanicity, belongs to an ROR. We restrict our analysis to the former West Germany, for which we have earlier waves of GSOEP. West Germany has 75 different Raumordnungsregionen in Germany (see Figure 3 for detailed information on RORs). The GSOEP reports households' ROR information starting from 1985; thus we conduct the empirical analysis with the 1985 wave of GSOEP. The GSOEP provides information on cities where individuals are residing in 1985 onwards. The GSOEP also asks respondents whether they still live in the city or area where they grew up. ${ }^{11}$ This question helps us to identify whether individuals still reside in their childhood city or area.

\footnotetext{
${ }^{11}$ The GSOEP question based on which the movers are identified in this paper is "Do you still live in the city or area where you grew up until age 15?" with three possible responses "yes, still", "yes, again", and "no". I have coded
} 
Table 1 presents the descriptive statistics for population-weighted city-level percentage of Jewish population and variables measuring conditions before the Nazi Regime. Table 1 shows that on average, 1.13 percent of the population was Jewish in West Germany in 1933. However, there was a sizable variation across cities in the density of Jews; the Jewish percentage in cities with above-average Jewish population was almost three times as in cities with below-average Jewish population. For example, almost 4 percent of the population was Jewish in Berlin and Frankfurt. However, the Jewish population constituted only 0.4 percent of the population in Bremen and Essen. Table 1 also highlights that cities with higher Jewish population are larger in area and have higher population density and average income per capita in 1932. This underlines the fallacy of relying only on cross-city variation in the Jewish population to identify the effects of Holocaust; it is likely incorrect to attribute all differences in children's outcomes between cities of varying Jewish population to the expulsions because there are other differences between these cities that are correlated with these outcomes too. The difference-in-differences strategy we propose uses within-city cross-cohort variation to identify the effects of Holocaust, and controls for differences between birth cohorts that are common across German cities. ${ }^{12}$

Table 2 shows the descriptive statistics of the outcomes and the main individual-level control variables we will use in our estimation. One of the main outcomes of interest is years of schooling completed. While most of our regression analysis is with the years-of-schooling measure, we will also present results using the highest educational attainment categories. We will also analyze political outcomes. As a measure of political outcome, we will use an indicator

individuals who answered this question as "yes, still" and "yes, again" as non-movers. The interpretation of city or area was left to the perception of the respondents; therefore it is likely that individuals are coded as movers even though they relocated within the same ROR rendering their exposure to WWII destruction unchanged.

${ }^{12}$ There may be a concern that the observed differences in levels of city size and per capita income suggest possible differences in trends in children's outcomes. Below, we assess whether there are differential trends by doing a falsification test/control experiment using data on cohorts who would have completed their schooling before the Nazi Regime. 
which shows whether an individual has a general interest in politics. These outcomes are measured five decades after the Holocaust and reflect the outcomes of German-natives who lived to 1985 or later.

\section{Estimation Results}

\subsection{Educational Attainment}

Table 3 reports the results of estimating Equation (1) where the dependent variable is completed years of schooling. Each column is from a separate regression that controls for city and birth year fixed effects along with female and rural dummies. The difference-in-differences estimate, $\beta$, is reported in the first row. It is negative and significant at $95 \%$ level of confidence in every specification. Column (1) displays the difference-in-difference estimates for the entire population. Column (1) has an estimated $\beta$ of -0.39 which suggests that the dismissal of Jewish population caused school-aged children to attain on average 0.4 fewer years of schooling. This is the difference-in-difference coefficient $\beta(-0.4)$ multiplied by the average population-weighted Jewish percentage in $1933(1.13 \%)$ presented in Table 1. To gain a better understanding on the magnitude of $\beta$, we can also compare the educational attainment of school-aged children who were in Frankfurt (one of the cities with highest percentage of Jewish population in 1933 where 3.25 percent of the city's population was Jewish) to children who were in Bremen (one of the cities with lowest percentage of Jewish population where 0.4 percent of the city's population was Jewish) during Nazi Regime. ${ }^{13}$ Using this comparison, Column (1) suggests that children in Frankfurt had 1.1 fewer years of schooling compared to children in Bremen as a result of Holocaust.

\footnotetext{
${ }^{13}$ These two cities were very similar, but there were a higher number of Jewish inhabitants residing in Frankfurt; therefore Frankfurt experienced a greater reduction in Jewish population.
} 
Columns (2) and (3) of Table 3 present the results incorporating family background characteristics, such as father's and mother's educational attainment which are likely to serve as a proxy for parents' economic status. The first row in these columns reports the estimation results for children whose parents had basic school degree (Hauptschule) or less. ${ }^{14}$ Results summarized in columns (2) and (3) reveal that children with less educated parents had a greater reduction in their educational attainment (first row). On the other hand, interaction terms suggest that the negative effect of Holocaust is mitigated for children whose parents have more than basic education (second and third rows). This differential effect may work literally through parental education (e.g., more educated parents value education more, and so ensure their children are educated too even if negative shocks occur) or through other channels correlated with parental education such as family income or wealth (e.g., rich families can afford to educate their children, and can hire private tutors or send children to boarding schools when necessary).

To assure that, results summarized in Panel A are not driven by the choice of Holocaust measure, in Panel B, we estimate the same specification using an alternative measure. The alternative measure we use is the change in the percentage of Jewish population in German cities between 1933 and 1946. Our results are quantitatively similar if we use this alternative Holocaust measure since the fraction of Jewish population was zero or very small in almost all German cities by the end of WWII, with exception of Berlin.

Table 3 shows that the reduction in the Jewish population decreases children's years of schooling by 0.4 years. It is also useful to estimate the effect of Holocaust on educational attainment, i.e., probability of completing certain degrees. For example, does the effect in Table 3 come from a reduction in middle school, secondary school, college or graduate school

\footnotetext{
${ }^{14}$ The basic school diploma (Hauptschule) is granted after 9 years of schooling in Germany. As shown in Table 2, the majority of children have parents with basic education or less ( $81 \%$ of fathers and $87 \%$ of mothers in our sample completed basic education or less).
} 
completion? To assess at what level of education the adverse effect of Holocaust is present, we estimate the following baseline specification:

$$
\mathrm{Y}_{\text {irtm }}=\alpha+\sum_{m=7}^{18}\left(\text { JewishFraction }_{r} \times \text { AffectedCohort }_{i t}\right) \beta_{m}+\delta_{r}+\gamma_{t}+\pi^{\prime} \mathbf{X}_{\text {irtm }}+\varepsilon_{\text {irtm }}
$$

where the outcome of interest, $\mathrm{Y}_{\text {irtm }}$ is a dummy variable that indicates whether the individual $i$ born in year $t$, in city $r$, completed $m$ years of schooling or more. $\beta_{m}$, for $\mathrm{m}=7$ to 18 , is the estimated effect of the Holocaust on probability of completing each levels of education. The estimation results for difference-in-difference estimates are plotted in Figure 4 (the 95\% and 90\% confidence intervals are also shown). Each point in Figure 4 is from a separate regression where the outcome is a dummy variable that takes a value of 1 if individual completed $m$ years of schooling or more and zero otherwise. Figure 4 shows that the exclusion of Jewish professionals disrupts individual's educational formation in all levels of education-the point estimates are always negative. Figure 4 reports that the affected cohorts in a city with an average Jewish population were 5-6 percent less likely to have some college (13-14 years of schooling), 3 percent less likely to have a college degree (16 years of schooling) and 4 percent less likely to have a graduate degree (17-18 years of schooling) because of the expulsion of Jewish population. Taken together, Figure 4 suggests that young adults at the technical schools and universities accounted for most of the detrimental impacts of Holocaust. As stated in Section 3, after civil service law was put into effect in 1933, Jewish professors in all fields were dismissed from German universities. As discussed in Section 2, Waldinger (2010) shows that the dismissal of Jewish professors during the Nazi Regime had negative long-term consequences for their $\mathrm{PhD}$ students. Our results suggest that the detrimental effects of the persecution of Jewish 
professionals were far beyond their $\mathrm{PhD}$ students. As illustrated in Figure 4, the dismissal of Jewish professionals substantially reduced the likelihood of German children to attend and complete college and/or post graduate studies.

A potential confounding factor for results summarized in Table 3 is probability of the nonrandom migration across cities. For example, due to the dismissal and change in the structure of the cities, some of the German citizens may have moved to other parts of the country. Alternatively, the dismissal of Jewish professionals might have increased the available jobs in these cities and attract economic migrants and Nazi supporters seeking to fill the positions. Both types of migration might induce selection bias in the analysis of the long-run impacts of Holocaust on children's outcomes. ${ }^{15}$ To address whether individuals' migration decision is based on the city's Jewish population, we estimate Equation (1) using the probability of moving as the dependent variable; results are reported in Table 4, Panel A. Individuals are coded as movers if they report that they no longer reside in their childhood city or area in 1985. Treatment and control groups for this specification are the same as in the education analysis. The difference-indifference estimates for probability of moving are close to zero and statistically insignificant in every specification. This finding bolsters our confidence that individuals did not choose their final destination according to the fraction of the Jewish population in the city in 1933.

Panel B provides further evidence on lack of systematic migration. The analysis in Panel B is restricted to individuals who still live in the city or area where they grew up (hereafter, "non-movers"). Panel B shows that the difference-in-difference estimates for non-movers are very similar to the estimates for the entire population (D-D estimates for the entire population

\footnotetext{
${ }^{15}$ It is well documented that Germany has historically low levels of geographic mobility in comparison to the U.S. and U.K. and that mobility is particularly low during childhood and early adulthood (Rainer and Siedler, 2005; Hochstadt, 1999). For example, mobility rates were very low during the period 1950-1970 among native Germans in former West Germany, with an annual migration rate between states of around 0.02, defined as the ratio of number of migrants to or from a state within one year by the population of that state (Hochstadt, 1999).
} 
and non-movers lie within each other's $95 \%$ confidence intervals). This empirical evidence presented supports our previous findings that non-movers are not differentially impacted by the expulsion of Jewish population and suggests that the non-random migration is unlikely to be a concern.

Results presented in Table 3 rest on the assumption that in the absence of Holocaust, the difference in educational attainment between the affected group and the control group would have been similar across cities (the parallel trend assumption). That is, the coefficient for interaction between dummy for being born 1915-1923 and city-level ex ante Jewish population would be zero in the absence of persecutions. However, if there were differential cohort trends in educational attainment between cities with higher Jewish population and lower Jewish population, then it would not be possible to interpret the difference-in-differences estimate as due to exile of Jews. To assess the validity of the identifying assumption, we perform the following falsification test/control experiment. We restrict the empirical analysis to older cohorts who would have completed their schooling before the outset of Nazi Regime. We code the oldest cohorts (i.e. those born between 1900 and 1906) as the "Placebo" affected cohort and cohorts born between 1907 and 1914 as the "Placebo" control cohort though of course there is no true treatment here. If there are no differential trends, then the difference-in-differences estimates should be zero, which is indeed what we find (see Panel C of Table 4). The results in Panel C lend credence to the identification assumption in Equation (1) and support the interpretation of the difference-in-difference estimates as due to exclusion of Jewish population as opposed to some city-specific cohort trend. 


\subsubsection{Historical Controls}

During the time period we focus on our paper, Germany also experienced other major political and economic events including the Nazi Regime, World War II and Great Depression. It is possible that German cities with higher Jewish population might have been differentially impacted by these historical events, which may raise potential concerns on the analyses presented in Table 3 and Figure 4. In this subsection, we formally test whether our results are confounded by these events; results are presented in Table 5. The first row in Table 5 reports the difference-in-difference coefficient for the ex ante Jewish population controlling for other historical events.

One of the potential confounding factors is the exposure to WWII. The WWII destruction experienced by the city might have been associated with the Jewish population residing in the city during the Nazi Regime. To address whether the school-aged children had been impacted from WWII destruction differentially, we estimate the baseline specification controlling for the interaction between city-level wartime destruction measure (rubble in $\mathrm{m}^{3}$ per capita) and an indicator for being in the affected group. Column (2) shows that the difference-in-difference estimate for WWII destruction is very small and statistically insignificant suggesting that there was no meaningful variation in exposure to wartime destruction across cities of varying ex ante Jewish population.

Another related concern is refugees or people who fled to Germany from the former parts of Germany and Soviet Zone/GDR after WWII. It is possible that refugees might have settled in cities with higher ex ante Jewish population to fill the positions vacated from Jewish professionals. As an attempt to address this potential concern, we use the official 1961 city-level refugee data provided by Redding and Sturm (2008). We add the percentage of refugees in 1961 
interacted with being in the affected cohort as a control into our baseline specification; results are summarized in Column (3). We find no evidence for differential impacts of refugees.

Another potential confounding factor may be the economic crisis Germany experienced during early 1930s. The economic crisis and subsequent unemployment would have had differential impacts in cities with higher Jews, altering the incentives for human capital investment among German children. In a high unemployment environment, these children might have chosen to work in lower skill jobs instead of investing in higher education. Alternatively, these adverse labor market conditions may have induced them to stay longer at school and acquire more education. As an attempt to address this potential concern, in Column (4), we use city-level unemployment rate in 1932 as a proxy for the macroeconomic conditions in German cities. The difference-in-difference estimate for ex ante Jewish population remains virtually unchanged when we control for the interaction between unemployment rate in 1932 and a dummy variable for being in the affected cohort, which suggests that school-aged children's educational attainment was not differentially impacted by the city-level unemployment rate.

An additional concern is differential Nazi support. It is possible that cities with higher ex ante Jewish population might have had a stronger support for Nazi Party and Anti-Semitic policies implemented during the Nazi Regime. We account for this potential concern in Column (5). We include the interaction between the percentage of votes Nazi Party (NSDAP) received in the last democratic federal election in 1932 and being in the affected cohort into the baseline specification. This analysis yields similar difference-in-difference estimate as in the baseline specification.

With the "Law for the Restoration of the Professional Civil Service", together with Jewish population, all members of the Communist party were also expelled from civil service in 
Germany. Deichmann (2001) and Waldinger (2010) however suggest that only small fraction of the professors were dismissed because of being "politically unreliable"; therefore it is unlikely that our results are confounded by the differential Communist Party support in German cities. However, as robustness, we collect city-level data on the percentage of votes Communist Party of Germany (KPD) received in the federal election in 1932 to account for the potential effects of dismissal of the Community Party members. Using this information, in Column (6), we control for the interaction between the percentage of votes received by Communist Party of Germany in 1932 and being in the affected cohort in our analysis. Column (6) mimics the results presented in the previous columns and lends credence to our findings.

In the last column of Table 5, we control for all potential confounding factors together. The difference-in-difference estimate for the ex ante Jewish population remains to be economically and statistically significant in this specification. Taken together, findings presented in Table 5 suggest that the dismissal of Jewish professionals has detrimental long-term effects on German children's educational attainment even after we account for the other major political and economic events Germany had experienced including Great Depression, Nazi and Communist Party support and WWII.

\subsubsection{Channels and Heterogeneity}

In this subsection, we provide formal evidence on the heterogeneity and potential mechanisms through which persecution of the Jewish population may have affected the schoolaged children. The results are reported in Table 6. In Column (2), we allow the difference-indifference estimate to vary by child's gender. Historical accounts document that college and graduate students were predominantly male during this time period (German Statistical 
Yearbook, 1935). Column (2) indeed shows that the difference-in-difference estimate for males is larger in magnitude compared to females. Historical records further suggest that two-thirds of Jews in Germany were concentrated in cities with over 100,000 inhabitants (Kaplan, 2005); therefore individuals residing in urban areas might have been impacted more from the loss of Jewish population. In Column (3), we allow the impact of the loss of Jewish population to vary by urban status. We find no differential effects for individuals residing in urban areas.

Additionally, one may expect the Holocaust effect to be non-linear, e.g., ex ante fraction of Jews surpasses a certain level then the detrimental effects become especially large, otherwise the effects are modest or negligible. To explore whether the negative effects of expulsions are more pronounced in cities with highest ex ante Jewish population, we divide the Jewish population intensity measure into quartiles. The estimation results from this specification show that the adverse effects of Holocaust are larger in cities that lost a higher fraction of their population due to the Holocaust. Children in top quartile attain 0.6 fewer years schooling relative to the control group; this effect is twice as large as for the bottom quartile.

Having shown that school-aged children have lower educational attainment due to Holocaust, it is of interest to explore the channels underlying this causal association. Is the estimated effect of Holocaust on children's schooling working through the supply side of the education production function such as the dismissal of Jewish professors and school teachers from German schools? Are demand side factors such as liquidity constraints, decline in education quality and employment opportunities at work? Figure 1 and Figure 2 present the decline in the number of university professors and school teachers between 1932 and 1934 by the Jewish population in the city, respectively. ${ }^{16}$ From these figures, it appears that cities with higher ex ante Jewish population had a greater decline in both the number of university

\footnotetext{
${ }^{16}$ For number of dismissed Science professors, we use figures from Waldinger (2011).
} 
professors and teachers after the Nazi Party seized the power in 1933. In addition, in Table 6, Columns (5) and (6) formally test the impact of the professors' and school teachers' dismissals on children's years of schooling. We find that school-aged children in cities with higher fraction of ex ante Jewish population receive less schooling because the schools and universities are defunct due expulsion of Jewish professors and school teachers. Of course, undoubtedly additional demand side mechanisms may be at work too, but dismissal of educators seems to be a plausible and an important mechanism for the effects of Holocaust on schooling.

\subsection{Political Outcomes}

Now, we turn to estimating the impact of the dismissal and exile of Jewish population on German children's long-term political outcomes. The political outcome we will measure is an indicator of whether individual has a general interest in politics. An extensive literature on political development documents that size of the middle class is important in promoting political development in the society (Acemoglu, Hassan and Robinson, 2010; Acemoglu and Robinson, 2006). Hence, the overwhelming majority of Jewish population in Germany were highly educated and belonged to the middle and high class (Yahil, 1990), a likely mediator for these long-run effects, especially for political outcomes, is the change in the social structure in German cities due to the loss of Jewish population.

The outcome interest in Table 7 is a dummy variable which indicates whether individual has a general interest in politics. It takes a value of 1 if an individual reports that she/he has a very strong or strong interest in politics and zero if an individual has weak or no interest in politics. The treatment and control groups described above for the education analysis also apply for this outcome. As summarized in Table 7, all specifications show that expulsion of Jewish 
population had a long-lasting, detrimental effect on individual's interest in politics that is significant at the 5\% significance level. In Column (1), the difference-in difference estimate is 0.08 indicating that German children, who experienced Holocaust, therefore lost a considerable fraction of the middle and high class citizens in their city are on average about $8 \%$ less likely to have an interest in politics in adulthood than the others.

Previous research by Milligan, Moretti, and Oreopoulos (2004) and Siedler (2010) show that an increase in educational attainment improves interest in politics and civil participation in US and Germany, respectively. It is therefore possible that the negative effects of the Jewish persecutions on political outcomes are mainly working through a decline in educational attainment. To assess the role of educational attainment on the political outcomes, we control for years of schooling in Panel B. This analysis shows that reduction in educational attainment explains a considerable part of the findings in Panel A. However, the negative effects of the ex ante Jewish population on German children's political interest remain to be economically and statistically significant in Panel B. This suggests that reduction in educational attainment is not the only channel for the decline in individuals' interest in politics, leaving room for other channels such as decrease in size of the middle class and social capital.

To summarize, we find that the severity of Holocaust decreases the individual's interest in politics, even after we control for educational attainment. Previous research by Bellows and Miguel (2009; 2006) and Blattman (2009) however shows that exposure to armed conflict increased the post-conflict political participation in Sierra Leone and Uganda, respectively. The difference between these studies and our findings may stem from the fact that during the Nazi Regime, Germany predominantly lost the educated fraction of its population who were 
overwhelmingly members of middle and high class; however in Sierra Leone and Uganda, the burden of the civil conflicts was borne by the entire population.

\section{Conclusion}

This paper provides causal evidence on the long-term consequences of Jewish expulsions in Nazi Germany on educational attainment and political outcomes of German children. We combine a unique city-level dataset on the fraction of Jewish population residing in Germany during the Nazi Regime with individual survey data from the German Socio-Economic Panel (GSOEP) to study the unintended long-run legacies of the persecution of Jews. Our identification strategy exploits the plausibly exogenous city-by-cohort variation in the intensity of Jewish population in Germany as a unique quasi-experiment. We find that the dismissal and exile of Jewish population caused Germans who were school-aged during Nazi Regime to complete fewer years of schooling, be less likely to go to a technical school or university and have a graduate degree and report lower interest in politics in the future. The reduction in educational attainment is borne disproportionately by people living in cities with higher fraction of Jewish population, and whose parents were less educated. An important channel for the effect of Holocaust on educational attainment appears to be the dismissal and exile of university professors and teachers. However, demand side factors such as liquidity constraints, decline in education quality and employment opportunities may be also at work.

The findings in this paper shed light on the potential long-term legacies of large-scale human capital loss that could be caused by economic or political turmoil in the countries. Our findings show that cities that experienced a dramatic decline in the number of high skilled professionals not only experience deterioration in macro-level outcomes, but such large-scale 
human capital loss has more pervasive consequences along human dimensions. The detrimental effects of the Jewish persecutions in Nazi Germany are still present five decades after Holocaust; therefore our findings underline the importance of policies targeting primarily school-aged children after large-scale negative shocks. 


\section{References}

Acemoglu, Daron, Tarek Hassan and James Robinson. Forthcoming. "Social Structure and Development: A Legacy of the Holocaust in Russia." The Quarterly Journal of Economics.

Acemoglu, Daron and James Robinson. 2006. Economic Origins of Dictatorship and Democracy. New York: Cambridge University Press.

Akbulut-Yuksel, Mevlude. 2009. "Children of War: The Long-Run Effects of Large-Scale Physical Destruction and Warfare on Children," IZA Discussion Paper 4407.

Akresh, Richard and Damien de Walque. 2008. "Armed Conflict and Schooling: Evidence from the 1994 Rwanda Genocide.” Households in Conflict Network Working Papers 47.

Beine, Michel, Frederic Docquier and Hillel Rapoport. 2008. "Brain Drain and Human Capital Formation in Developing Countries: Winners and Losers." Economic Journal, 118: 631-652.

Beine, Michel, Frederic Docquier and Hillel Rapoport. 2001. "Brain Drain and Economic Growth: Theory and Evidence." Journal of Development Economics, 64(1): 275-289.

Bellows, John and Edward Miguel. 2009. "War and Local Collective Action in Sierra Leone." Journal of Public Economics, 93 (11-12): 1144-1157.

Bellows, John and Edward Miguel. 2006. "War and Institutions: New Evidence from Sierra Leone.” American Economic Review, 96 (2): 394-399.

Bertrand, Marrianne, Esther Duflo and Sendhil, Mullainathan. 2004. "How much should We Trust Difference-in-Difference Estimates?” Quarterly Journal of Economics, 119 (1): 249-275.

Blattman, Christopher and Edward Miguel. 2010. "Civil War." Journal of Economic Literature, 48(1): 3-57.

Blattman, Christopher. 2009. "From Violence to Voting: War and Political Participation in Uganda." American Political Science Review, 103(2): 231-47.

Carrington, William and Enrica Detragiache. 1998. "How Big is the Brain Drain?" IMF Working Papers 98/102.

Case, Anne and Cally Ardington. 2006. "The Impact of Parental Death on School Outcomes: Longitudinal Evidence from South Africa." Demography, 43(3): 401-420.

Case, Anne, Christina Paxson and Joseph Ableidinger. 2004. "Orphans in Africa: Parental Death, Poverty, and School Enrollment." Demography, 41(3): 483-508. 
Deichmann, Ute. 2001. Fluechten, Mitmachen, Vergessen - Chemiker und Biochemiker in der NS-Zeit. Weinheim: Wiley-VCH Verlag.

De Walque, Damien and Philip Verwimp. 2010. "The Demographic and Socio-Economic Distribution of Excess Mortality during the 1994 Genocide in Rwanda." Journal of African Economies, 19 (2): 141-162.

Einer, Friedrich. 1949. "Ergebnisse der Volks- und Berufszählung." Statistisches Jahrbuch Deutscher Gemeinden, 144-166.

Evans, David and Edward Miguel. 2007. "Orphans and Schooling in Africa: A Longitudinal Analysis." Demography, 44(1): 35-57.

Evans, Richard. 2005. The Third Reich in Power, 1933-1939. Penguin Press HC.

Fortson, Jane, 2011. "Mortality Risk and Human Capital Investment: The Impact of HIV/AIDS in Sub-Saharan Africa." Review of Economics and Statistics, 93(1): 1-15.

Grosfeld, Irena, Alexander Rodnyansky and Ekaterina Zhuravskaya. 2011. "Persistent AntiMarket Culture: A Legacy of the Pale of Settlement and of the Holocaust." CEPR Discussion Paper 8316.

Hochstadt, Steve. 1999. Mobility and Modernity: Migration in Germany 1820-1989. Ann Arbor: University of Michigan Press.

Kästner, Friedrich. 1949. "Kriegsschäden: Trümmermengen, Wohnungsverluste, Grundsteuerausfall und Vermögensteuerausfall." Statistisches Jahrbuch Deutscher Gemeinden, 361-391.

Kaplan, Marion. 2005. Jewish Daily Life in Germany, 1618-1945. USA: Oxford University Press.

Kessner, Carl. 1935. "Ergebnisse der Volks- und Berufszählung." Statistisches Jahrbuch Deutscher Gemeinden, 346-373.

Klenow, P.J. and Rodriguez-Clare, A. 2005. Externalities and Growth. in (P. Aghion and S. Durlauf, eds.), Handbook of Economic Growth, Amsterdam: Elsevier-North Holland.

Lucas, Robert. 1988. "On the Mechanics of Economic Development." Journal of Monetary Economics, 22 (3): 3-42.

McKenzie, David, John Gibson and Steven Stillman. Forthcoming. "The Impacts of International Migration on Remaining Household members: Omnibus Results from a Migration Lottery Program." Review of Economics and Statistics. 
McKenzie, David and John Gibson. 2010. "The Development Impact of a Best Practice Seasonal Worker Policy." World Bank Policy Research Working Paper 5488.

Milligan, Kevin, Enrico Moretti and Philip Oreopoulos. 2004. "Does Education Improve Citizenship? Evidence from the U.S. and the U.K." Journal of Public Economics, 88 (9-10): 1667-1695.

Rainer, Helmut and Thomas Siedler. 2005. "O Brother, Where Art Thou? The Effects of Having a Sibling on Geographic Mobility and Labor Market Outcomes.” ISER Working Paper 18.

Redding, Stephen and Daniel Sturm. 2008. "The Costs of Remoteness: Evidence from German Division and Reunification." American Economic Review, 98(5): 1766-1797.

Shemyakina, Olga. Forthcoming. "The Effect of Armed Conflict on Accumulation of Schooling: Results from Tajikistan." Journal of Development Economics.

Siedler, Thomas. 2010. "Schooling and Citizenship in a Young Democracy: Evidence from Postwar Germany." Scandinavian Journal of Economics, 112 (2): 315 - 338.

Strauss, Herbert. 1983. International Biographical Dictionary of Central European Émigrés 1933-1945. Munich: Llh Publishing.

Yahil, Leni. 1991. The Holocaust: The Fate of European Jewry, 1932-1945. USA: Oxford University Press.

Waldinger, Fabian. Forthcoming. "Peer Effects in Science - Evidence from the Dismissal of Scientists in Nazi Germany." Review of Economic Studies.

Waldinger, Fabian. 2010. "Quality Matters: The Expulsion of Professors and the Consequences for Ph.D. Student Outcomes in Nazi Germany." Journal of Political Economy, 118 (4): 787-831. 
Table 1. Descriptive Statistics for the Jewish Population in Germany

\begin{tabular}{|c|c|c|c|c|c|}
\hline & All & $\begin{array}{l}\text { Cities with above } \\
\text { avg. Jewish pop. } \\
\text { (2) }\end{array}$ & $\begin{array}{l}\text { Cities with below } \\
\text { avg. Jewish pop. } \\
\text { (3) }\end{array}$ & $\begin{array}{c}\text { Difference } \\
\text { s.e(difference) } \\
(4) \\
\end{array}$ & \\
\hline \% of Jews in 1946 & $\begin{array}{c}0.155 \\
(0.280)\end{array}$ & $\begin{array}{c}0.283 \\
(0.376)\end{array}$ & $\begin{array}{c}0.074 \\
(0.137)\end{array}$ & $\begin{array}{c}0.209 \\
(0.013)\end{array}$ & $* * *$ \\
\hline Area in $\mathrm{km}^{2}$ in 1933 & $\begin{array}{c}264.557 \\
(209.392)\end{array}$ & $\begin{array}{c}314.519 \\
(251.133)\end{array}$ & $\begin{array}{c}233.382 \\
(171.364)\end{array}$ & $\begin{array}{c}81.137 \\
(10.074)\end{array}$ & *** \\
\hline Population in 1933 & $\begin{array}{c}403,905 \\
(353,601)\end{array}$ & $\begin{array}{c}509,281 \\
(341,166)\end{array}$ & $\begin{array}{c}338,154 \\
(345,362)\end{array}$ & $\begin{array}{l}171,127 \\
(16,836)\end{array}$ & $* * *$ \\
\hline Unemployment Rate & $\begin{array}{c}9.850 \\
(2.432)\end{array}$ & $\begin{array}{c}9.869 \\
(2.148)\end{array}$ & $\begin{array}{c}9.838 \\
(2.595)\end{array}$ & $\begin{array}{c}0.032 \\
(0.119)\end{array}$ & \\
\hline Nazi Support in 1932 & $\begin{array}{l}31.781 \\
(7.403)\end{array}$ & $\begin{array}{l}33.945 \\
(6.430)\end{array}$ & $\begin{array}{l}30.431 \\
(7.649)\end{array}$ & $\begin{array}{c}3.515 \\
(0.353)\end{array}$ & $* * *$ \\
\hline Communist Party Support in 1932 & $\begin{array}{l}17.516 \\
(6.230)\end{array}$ & $\begin{array}{l}17.311 \\
(5.074)\end{array}$ & $\begin{array}{l}17.644 \\
(6.852)\end{array}$ & $\begin{array}{l}-0.333 \\
(0.305)\end{array}$ & \\
\hline Rubble per Capita & $\begin{array}{l}15.736 \\
(7.564)\end{array}$ & $\begin{array}{c}17.348 \\
(17.348)\end{array}$ & $\begin{array}{l}14.712 \\
(6.124)\end{array}$ & $\begin{array}{c}2.636 \\
(3.665)\end{array}$ & \\
\hline N Max. & 1762 & 677 & 1085 & 1762 & \\
\hline
\end{tabular}

Notes: The sample consists of 75 Regional Policy Regions (RORs or cities) in the territory of former West Germany. The means presented are weighted by population. Standard deviations are in parentheses. 
Table 2. Descriptive Statistics, GSOEP Data

\begin{tabular}{|c|c|c|c|}
\hline & $\begin{array}{l}\text { All } \\
(1) \\
\end{array}$ & $\begin{array}{l}\text { Cities with above } \\
\text { avg. Jewish pop. } \\
(2)\end{array}$ & $\begin{array}{l}\text { Cities with below } \\
\text { avg. Jewish pop. } \\
(3)\end{array}$ \\
\hline Years of Schooling & $\begin{array}{l}11.533 \\
(2.412)\end{array}$ & $\begin{array}{l}11.690 \\
(2.552)\end{array}$ & $\begin{array}{l}11.435 \\
(2.316)\end{array}$ \\
\hline Has High School Diploma & $\begin{array}{c}0.603 \\
(0.489)\end{array}$ & $\begin{array}{c}0.600 \\
(0.490)\end{array}$ & $\begin{array}{c}0.604 \\
(0.489)\end{array}$ \\
\hline $\begin{array}{l}\text { Has More than High School } \\
\text { Diploma }\end{array}$ & $\begin{array}{c}0.180 \\
(0.385)\end{array}$ & $\begin{array}{c}0.179 \\
(0.383)\end{array}$ & $\begin{array}{c}0.182 \\
(0.386)\end{array}$ \\
\hline Interest in Politics & $\begin{array}{c}0.363 \\
(0.481)\end{array}$ & $\begin{array}{c}0.366 \\
(0.482)\end{array}$ & $\begin{array}{c}0.362 \\
(0.481)\end{array}$ \\
\hline Mother with Basic Education & $\begin{array}{l}0.873 \\
(0.333)\end{array}$ & $\begin{array}{l}0.865 \\
(0.342)\end{array}$ & $\begin{array}{l}0.878 \\
(0.327)\end{array}$ \\
\hline Father with Basic Education & $\begin{array}{l}0.812 \\
(0.391)\end{array}$ & $\begin{array}{l}0.799 \\
(0.401)\end{array}$ & $\begin{array}{l}0.821 \\
(0.384)\end{array}$ \\
\hline Age & $\begin{array}{l}40.825 \\
(17.045)\end{array}$ & $\begin{array}{l}41.016 \\
(17.014)\end{array}$ & $\begin{array}{l}40.706 \\
(17.072)\end{array}$ \\
\hline Female & $\begin{array}{l}0.528 \\
(0.499)\end{array}$ & $\begin{array}{l}0.526 \\
(0.500)\end{array}$ & $\begin{array}{l}0.530 \\
(0.499)\end{array}$ \\
\hline Urban & $\begin{array}{l}0.631 \\
(0.483)\end{array}$ & $\begin{array}{l}0.619 \\
(0.486)\end{array}$ & $\begin{array}{l}0.639 \\
(0.481)\end{array}$ \\
\hline $\mathrm{N} \max$. & 1762 & 677 & 1085 \\
\hline
\end{tabular}

Notes: Data are from 1985 GSOEP. The sample consists of individuals born between 1915 and 1960 . Individuals born between 1924 and 1950 are dropped from the analysis since they were exposed to WWII destruction and postwar reconstruction. Standard deviations are presented in parentheses. 
Table 3. Effects of Jewish Expulsions on Years of Schooling

\section{(1)}

(2)

Panel A: Percentage of Jews in 1933

\begin{tabular}{|c|c|c|c|}
\hline \% of Jews in 1933 X Born btw.1915-1923 & $\begin{array}{l}-0.3992^{* * *} \\
(0.1453)\end{array}$ & $\begin{array}{c}-0.3116^{* *} \\
(0.1286)\end{array}$ & $\begin{array}{l}-0.2811^{* *} \\
(0.1444)\end{array}$ \\
\hline $\begin{array}{l}\% \text { of Jews in } 1933 \times \text { Born btw. } 1915-1923 \\
X \text { Father has more than Basic Education }\end{array}$ & & $\begin{array}{c}0.4664 \\
(0.4214)\end{array}$ & $\begin{array}{c}0.6379 \\
(0.5229)\end{array}$ \\
\hline $\begin{array}{l}\% \text { of Jews in } 1933 \times \text { Born btw. } 1915-1923 \\
X \text { Mother has more than Basic Education }\end{array}$ & & & $\begin{array}{l}-0.3031 \\
(0.5112)\end{array}$ \\
\hline $\begin{array}{l}\mathrm{R}^{<} \\
\mathrm{N}\end{array}$ & $\begin{array}{l}0.163 \\
1756\end{array}$ & $\begin{array}{l}0.286 \\
1514\end{array}$ & $\begin{array}{l}0.309 \\
1493\end{array}$ \\
\hline
\end{tabular}

Panel B: Change in the Jewish Population by 1946

\begin{tabular}{|c|c|c|c|}
\hline Change in Jewish Pop. X Born btw.1915-1923 & $\begin{array}{l}-0.3979^{\star * *} \\
(0.1420)\end{array}$ & $\begin{array}{l}-0.3103^{* *} \\
(0.1262)\end{array}$ & $\begin{array}{r}-0.3092^{* *} \\
(0.1314)\end{array}$ \\
\hline $\begin{array}{l}\text { Change in Jewish Pop. X Born btw.1915-1923 } \\
\text { X Father has more than Basic Education }\end{array}$ & & $\begin{array}{c}0.5854 \\
(0.4650)\end{array}$ & $\begin{array}{c}0.7084 \\
(0.5510)\end{array}$ \\
\hline $\begin{array}{l}\text { Change in Jewish Pop. X Born btw.1915-1923 } \\
\text { X Mother has more than Basic Education }\end{array}$ & & & $\begin{array}{l}-0.2767 \\
(0.5540)\end{array}$ \\
\hline $\mathrm{R}^{2}$ & 0.163 & 0.287 & 0.31 \\
\hline $\mathrm{N}$ & 1756 & 1514 & 1493 \\
\hline
\end{tabular}

Notes: Standard errors clustered by cities are shown in parentheses. Asterisks denote significance levels $\left({ }^{*}=.10,{ }^{* *}=.05,{ }^{* * *}=.01\right)$. The control group is individuals born between 1951 and 1960. Each column is from a separate regression where main treatment effect varies by parental education in Columns (2)-(3). Each column controls for city and birth year fixed effects. Columns (2)-(3) control for main effects of parental human capital. Other controls in each regression are gender and rural dummies. 
(1)

(2)

(3)

\section{Panel A: Probability of Moving}

\% of Jews in 1933 X Born btw.1915-1923

$\%$ of Jews in 1933 X Born btw.1915-1923

$X$ Father has more than Basic Education

$\%$ of Jews in 1933 X Born btw.1915-1923

$\mathrm{X}$ Mother has more than Basic Education

$\mathrm{R}^{<}$

$\mathrm{N}$

$\begin{array}{ccc}-0.0493 & -0.0525 & -0.0486 \\ (0.0342) & (0.0371) & (0.0364) \\ & & \\ & 0.0422 & 0.0742 \\ & (0.0698) & (0.0942) \\ & & -0.0751 \\ & & (0.1239) \\ 0.128 & 0.158 & 0.155 \\ 1752 & 1512 & 1491\end{array}$

\section{Panel B: Non-movers Only}

\% of Jews in 1933 X Born btw.1915-1923

\% of Jews in 1933 X Born btw.1915-1923

$X$ Father has more than Basic Education

$\%$ of Jews in 1933 X Born btw.1915-1923

$\mathrm{X}$ Mother has more than Basic Education

$\mathrm{R}^{2}$

$\mathrm{N}$
$-0.4154^{* *}$

$(0.1850)$

0.181

990
$-0.3922^{* * *}$

$(0.1038)$

$-0.3128^{* * *}$

$(0.1060)$

0.0971

(0.5024)

$(0.4842)$

$-0.9644$

$(0.6021)$

0.274

852

0.302

842

\section{Panel C: Control Experiment}

$\%$ of Jews in 1933 X Born btw.1900-1906

$$
-0.0592
$$

\% of Jews in $1933 \times$ Born btw.1900-1906

$X$ Father has more than Basic Education

\% of Jews in $1933 \times$ Born btw.1900-1906

$\mathrm{X}$ Mother has more than Basic Education

$\mathrm{R}^{2}$

$\mathrm{N}$
$-0.0638$

(0.1124)

$-0.1203$

(0.1132)

$-0.2612$

(0.2469)

$-0.1708$

(0.3043)

$-0.3917$

(0.3775)

0.241

584

Notes: Standard errors clustered by cities are shown in parentheses. Asterisks denote significance levels $\left({ }^{*}=.10,{ }^{* *}=.05,{ }^{* * *}=.01\right)$. In Panels $\mathrm{A}$ and $\mathrm{B}$, the control group is individuals born between 1951 and 1960. In Panel C, sample consists of older cohorts who were born between 1900 and 1914 who would have completed their schooling before 1933. In Panel C, "Placebo" affected group is individuals born between 1900 and 1906 and "Placebo" control group is individuals born between 1907 and 1914. Each column is from a separate regression where main treatment effect varies by parental education in Columns (2) and (3). Each column controls for city and birth year fixed effects. Columns (2)-(3) also control for main effects of parental human capital. Other controls in each regression are gender and rural dummies. Individuals are coded as movers if they report that they no longer reside in their childhood city or area. 
Table 5. Historical Controls

\begin{tabular}{|c|c|c|c|c|c|c|c|}
\hline & $\begin{array}{c}\text { Baseline } \\
\text { Specification }\end{array}$ & $\begin{array}{l}\text { World War II } \\
\text { Destruction } \\
\end{array}$ & Refugees & $\begin{array}{c}\text { Unemployment } \\
\text { Rate }\end{array}$ & $\begin{array}{c}\text { Nazi } \\
\text { Support } \\
\end{array}$ & $\begin{array}{c}\text { Communist } \\
\text { Support }\end{array}$ & All \\
\hline & $(1)$ & $(2)$ & $(3)$ & $(4)$ & $(5)$ & $(6)$ & $(7)$ \\
\hline$\%$ of Jews in 1933 X Born btw.1915-1923 & $\begin{array}{c}-0.3992^{\star \star \star} \\
(0.1453)\end{array}$ & $\begin{array}{l}-0.3801^{* *} \\
(0.1449)\end{array}$ & $\begin{array}{c}-0.3613^{\star *} \\
(0.1572)\end{array}$ & $\begin{array}{c}-0.3980 * * * \\
(0.1471)\end{array}$ & $\begin{array}{c}-0.4437^{\star \star *} \\
(0.1391)\end{array}$ & $\begin{array}{l}-0.4021^{\star * *} \\
(0.1326)\end{array}$ & $\begin{array}{c}-0.4236^{\star *} \\
(0.1873)\end{array}$ \\
\hline Rubble per Cap. X Born btw.1915-1923 & & $\begin{array}{l}-0.0131 \\
(0.0151)\end{array}$ & & & & & $\begin{array}{l}-0.0083 \\
(0.0192)\end{array}$ \\
\hline$\%$ of Refugees X Born btw.1915-1923 & & & $\begin{array}{c}1.1017 \\
(1.7798)\end{array}$ & & & & $\begin{array}{c}0.1924 \\
(2.4777)\end{array}$ \\
\hline Unemployment Rate in 1932 X Born btw.1915-1923 & & & & $\begin{array}{c}0.0104 \\
(0.0389)\end{array}$ & & & $\begin{array}{c}0.0213 \\
(0.0688)\end{array}$ \\
\hline$\%$ of Votes to Nazi Party X Born btw.1915-1923 & & & & & $\begin{array}{c}0.0263 \\
(0.0169)\end{array}$ & & $\begin{array}{c}0.0209 \\
(0.0289)\end{array}$ \\
\hline$\%$ of Votes to Communist Party X Born btw.1915-1923 & & & & & & $\begin{array}{l}-0.0254 \\
(0.0159)\end{array}$ & $\begin{array}{l}-0.0189 \\
(0.0272)\end{array}$ \\
\hline $\mathrm{R}^{2}$ & 0.163 & 0.1630 & 0.1630 & 0.1629 & 0.1641 & 0.1637 & 0.1647 \\
\hline $\mathrm{N}$ & 1756 & 1,736 & 1,756 & 1756 & 1,756 & 1,756 & 1,736 \\
\hline
\end{tabular}

Notes: Standard errors clustered by cities are shown in parentheses. Asterisks denote significance levels $\left({ }^{*}=.10,{ }^{* *}=.05,{ }^{* \star *}=.01\right)$. The control group is individuals born between 1951 and 1960. Each column controls for city and year of birth fixed effects. Other controls in each regression are gender and rural dummies. 
Table 6. Heterogeneity in the Effects of Jewish Expulsions on Years of Schooling

\begin{tabular}{|c|c|c|c|c|c|c|}
\hline & & Source $o$ & erogeneity & & & \\
\hline & $\begin{array}{c}\text { Base } \\
\text { Results }\end{array}$ & Female & $\begin{array}{l}\text { Urban } \\
\text { Area }\end{array}$ & $\begin{array}{c}\text { Top Quartile } \\
\text { Jewish Population }\end{array}$ & $\begin{array}{c}\text { Change in } \\
\text { Professors (\%) }\end{array}$ & $\begin{array}{c}\text { Change in } \\
\text { Teachers (\%) }\end{array}$ \\
\hline & $(1)$ & $(2)$ & $(3)$ & $(4)$ & $(5)$ & (6) \\
\hline$\%$ of Jews in 1933 X Born btw.1915-1923 & $\begin{array}{l}-0.3992^{\star \star *} \\
(0.1453)\end{array}$ & $\begin{array}{l}-0.5259^{* *} \\
(0.2426)\end{array}$ & $\begin{array}{l}-0.4978^{\star \star *} \\
(0.1661)\end{array}$ & $\begin{array}{l}-0.5618^{\star *} \\
(0.3212)\end{array}$ & & \\
\hline $\begin{array}{l}\text { \% of Jews in } 1933 \text { X Born btw.1915-1923 } \\
\text { X Source of Heterogeneity }\end{array}$ & & $\begin{array}{l}0.2138 \\
(0.2161)\end{array}$ & $\begin{array}{c}0.1648 \\
(0.1247)\end{array}$ & & & \\
\hline Change in \% of Professors X Born btw.1915-1923 & & & & & $\begin{array}{l}-0.0441^{* *} \\
(0.0172)\end{array}$ & \\
\hline Change in \% of Teachers X Born btw.1915-1923 & & & & & & $\begin{array}{l}-0.0237^{\star \star} \\
(0.0103)\end{array}$ \\
\hline $\mathrm{R}^{2}$ & 0.1631 & 0.1732 & 0.1635 & 0.1521 & 0.1557 & 0.1684 \\
\hline $\mathrm{N}$ & 1756 & 1756 & 1756 & 1756 & 875 & 1272 \\
\hline
\end{tabular}

Notes: Standard errors clustered by cities are shown in parentheses. Asterisks denote significance levels $\left({ }^{*}=.10,{ }^{* *}=.05,{ }^{* * *}=.01\right)$. The control group is individuals born between 1951 and 1960. Columns (2)-(3) are from a separate regression where main treatment effect varies by source of heterogeneity. In Column (4), "Top Quartile Destruction" is adummy variable which takes a value of 1 for interaction of being in cities with highest Jewish fraction during the Nazi Regime and being born between 1915-1923. Each column controls for city and year of birth fixed effects. Other controls in each regression are gender and rural dummies. 


\begin{tabular}{|c|c|c|c|}
\hline & $(1)$ & $(2)$ & (3) \\
\hline \multicolumn{4}{|c|}{ Panel A: General Interest in Politics } \\
\hline$\%$ of Jews in 1933 X Born btw.1915-1923 & $\begin{array}{l}-0.0708^{* * *} \\
(0.0257)\end{array}$ & $\begin{array}{l}-0.0802^{* \star} \\
(0.0343)\end{array}$ & $\begin{array}{r}-0.0787^{* *} \\
(0.0350)\end{array}$ \\
\hline $\begin{array}{l}\% \text { of Jews in } 1933 \times \text { Born btw.1915-1923 } \\
\text { X Father has more than Basic Education }\end{array}$ & & $\begin{array}{c}0.0304 \\
(0.0535)\end{array}$ & $\begin{array}{c}0.0602 \\
(0.0798)\end{array}$ \\
\hline $\begin{array}{l}\% \text { of Jews in } 1933 \times \text { Born btw. } 1915-1923 \\
X \text { Mother has more than Basic Education }\end{array}$ & & & $\begin{array}{l}-0.0611 \\
(0.1176)\end{array}$ \\
\hline $\mathrm{R}^{<}$ & 0.115 & 0.151 & 0.155 \\
\hline $\mathrm{N}$ & 1759 & 1516 & 1495 \\
\hline \multicolumn{4}{|c|}{ Panel B: General Interest in Politics, Controlling for Education } \\
\hline \% of Jews in 1933 X Born btw.1915-1923 & $\begin{array}{l}-0.0507^{*} \\
(0.0262)\end{array}$ & $\begin{array}{l}-0.0679^{*} \\
(0.0338)\end{array}$ & $\begin{array}{c}-0.0687^{*} \\
(0.0346)\end{array}$ \\
\hline Years of Schooling & $\begin{array}{c}0.0585^{\star * *} \\
(0.0055)\end{array}$ & $\begin{array}{c}0.0521^{* * *} \\
(0.0055)\end{array}$ & $\begin{array}{c}0.0496^{* * *} \\
(0.0052)\end{array}$ \\
\hline $\begin{array}{l}\% \text { of Jews in } 1933 \times \text { Born btw.1915-1923 } \\
\text { X Father has more than Basic Education }\end{array}$ & & $\begin{array}{c}0.0069 \\
(0.0504)\end{array}$ & $\begin{array}{c}0.0289 \\
(0.0683)\end{array}$ \\
\hline $\begin{array}{l}\% \text { of Jews in } 1933 \times \text { Born btw.1915-1923 } \\
X \text { Mother has more than Basic Education }\end{array}$ & & & $\begin{array}{l}-0.0443 \\
(0.1058)\end{array}$ \\
\hline $\mathrm{R}^{2}$ & 0.187 & 0.201 & 0.199 \\
\hline $\mathrm{N}$ & 1753 & 1511 & 1490 \\
\hline
\end{tabular}

Notes: Standard errors clustered by cities are shown in parentheses. Asterisks denote significance levels $\left({ }^{*}=.10,{ }^{* *}=.05,{ }^{* \star *}=.01\right)$. The control group is individuals born between 1951 and 1960. Each column is from a separate regression where main treatment effect varies by by parental education in Columns (2) and (3). Each column controls for city and year of birth fixed effects. Columns (2) and (3) also control for main effects of parental education. Other controls in each regression are gender and rural dummies. Panel B controls for individual's years of schooling. 
Appendix Table 1. Effects of Jewish Expulsions on Years of Schooling

\begin{tabular}{|c|c|c|c|}
\hline & $(1)$ & $(2)$ & (3) \\
\hline$\%$ of Jews in 1933 X Born btw.1917-1926 & $\begin{array}{l}-0.4535^{\star * *} \\
(0.1313)\end{array}$ & $\begin{array}{c}-0.3117^{* *} \\
(0.1176)\end{array}$ & $\begin{array}{r}-0.2885^{* *} \\
(0.1219)\end{array}$ \\
\hline $\begin{array}{l}\% \text { of Jews in } 1933 \times \text { Born btw.1917-1926 } \\
X \text { Father has more than Basic Education }\end{array}$ & & $\begin{array}{l}0.6342^{*} \\
(0.3344)\end{array}$ & $\begin{array}{l}0.7368^{*} \\
(0.3830)\end{array}$ \\
\hline $\begin{array}{l}\% \text { of Jews in } 1933 \times \text { Born btw. } 1917-1926 \\
X \text { Mother has more than Basic Education }\end{array}$ & & & $\begin{array}{l}-0.1900 \\
(0.4485)\end{array}$ \\
\hline$R^{2}$ & 0.164 & 0.294 & 0.317 \\
\hline $\mathrm{N}$ & 1926 & 1661 & 1636 \\
\hline
\end{tabular}

Notes: Standard errors clustered by cities are shown in parentheses. Asterisks denote significance levels $\left({ }^{*}=.10,{ }^{* *}=.05,{ }^{* * *}=.01\right)$. The control group is individuals born between 1951 and 1960. Each column is from a separate regression where main treatment effect varies by parental education in Columns (2) and (3). Each column controls for city and year of birth fixed effects. Columns (2) and (3) control for main effects of parental human capital. Other controls in each regression are gender and rural dummies. 


\section{Appendix Table 2. Effects of Jewish Expulsions on Years of Schooling}

\begin{tabular}{lccc}
\hline \hline & $(1)$ & $(2)$ & $(3)$ \\
\hline \% of Jews in 1933 X Born btw.1915-1926 & $-0.4404^{* * *}$ & $-0.3099^{* *}$ & $-0.2883^{* *}$ \\
& $(0.1445)$ & $(0.1165)$ & $(0.1229)$ \\
\% of Jews in 1933 X Born btw.1915-1926 & & 0.512 & $0.6648^{*}$ \\
X Father has more than Basic Education & & $(0.3275)$ & $(0.3778)$ \\
\% of Jews in 1933 X Born btw.1915-1926 & & 0.3776 & -0.3159 \\
X Mother has more than Basic Education & & $(0.4068)$ & $(0.3735)$ \\
$\mathrm{R}^{2}$ & & & \\
$\mathrm{~N}$ & 0.166 & 0.298 & 0.319 \\
\hline \hline
\end{tabular}

Notes: Standard errors clustered by cities are shown in parentheses. Asterisks denote significance levels $\left({ }^{*}=.10,{ }^{* *}=.05,{ }^{* *}=.01\right)$. The control group is individuals born between 1951 and 1960 . Each column is from a separate regression where main treatment effect varies by parental education in Columns (2) and (3). Each column controls for city and year of birth fixed effects. Columns (2) and (3) control for main effects of parental human capital. Other controls in each regression are gender and rural dummies. 
Figure 1: Percentage of Dismissed Science Professors and the Jewish Population in German Cities

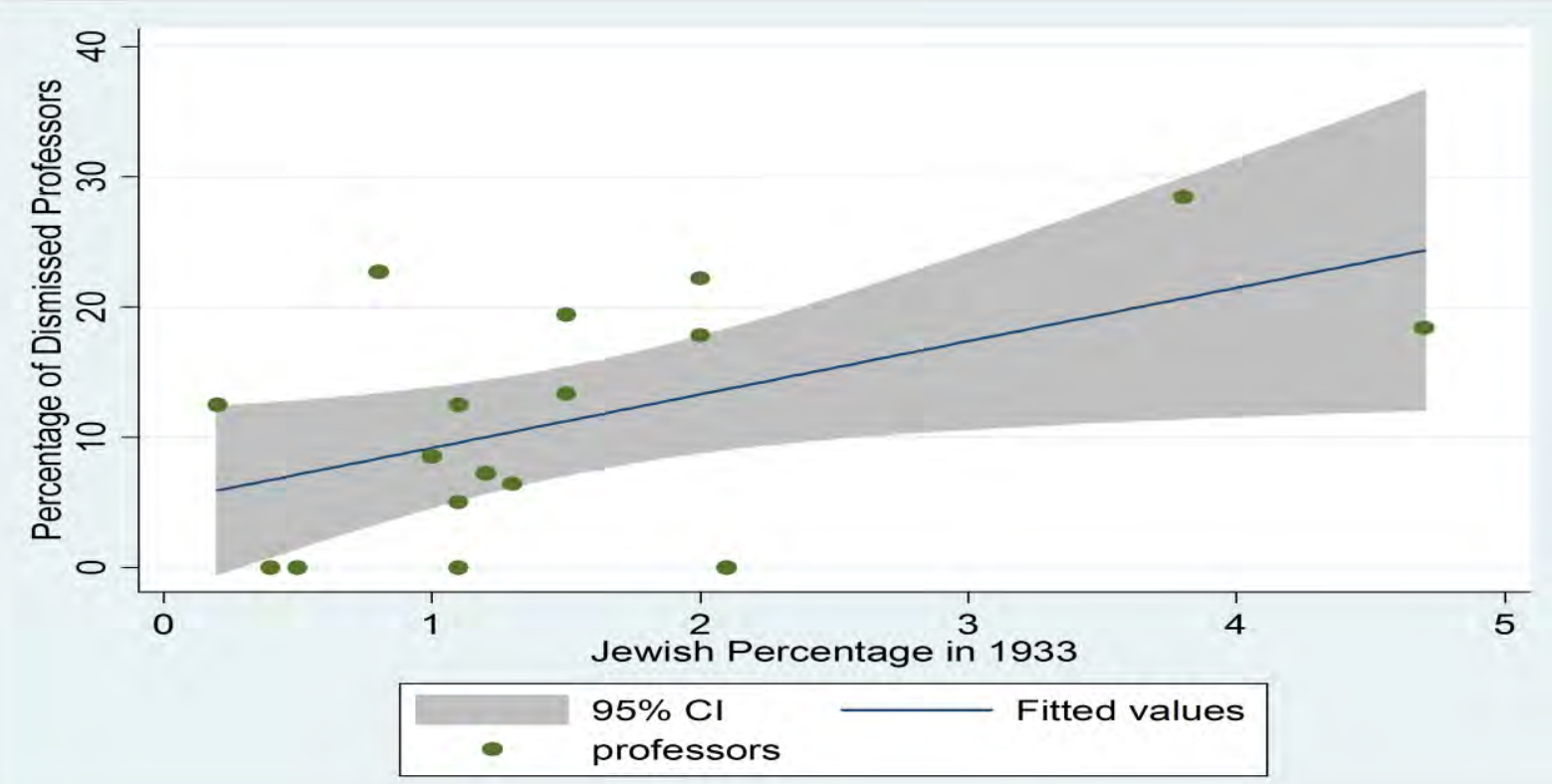

Source: Waldinger (2011)

Figure 2: Percentage of Dismissed School Teachers and the Jewish Population in German Cities

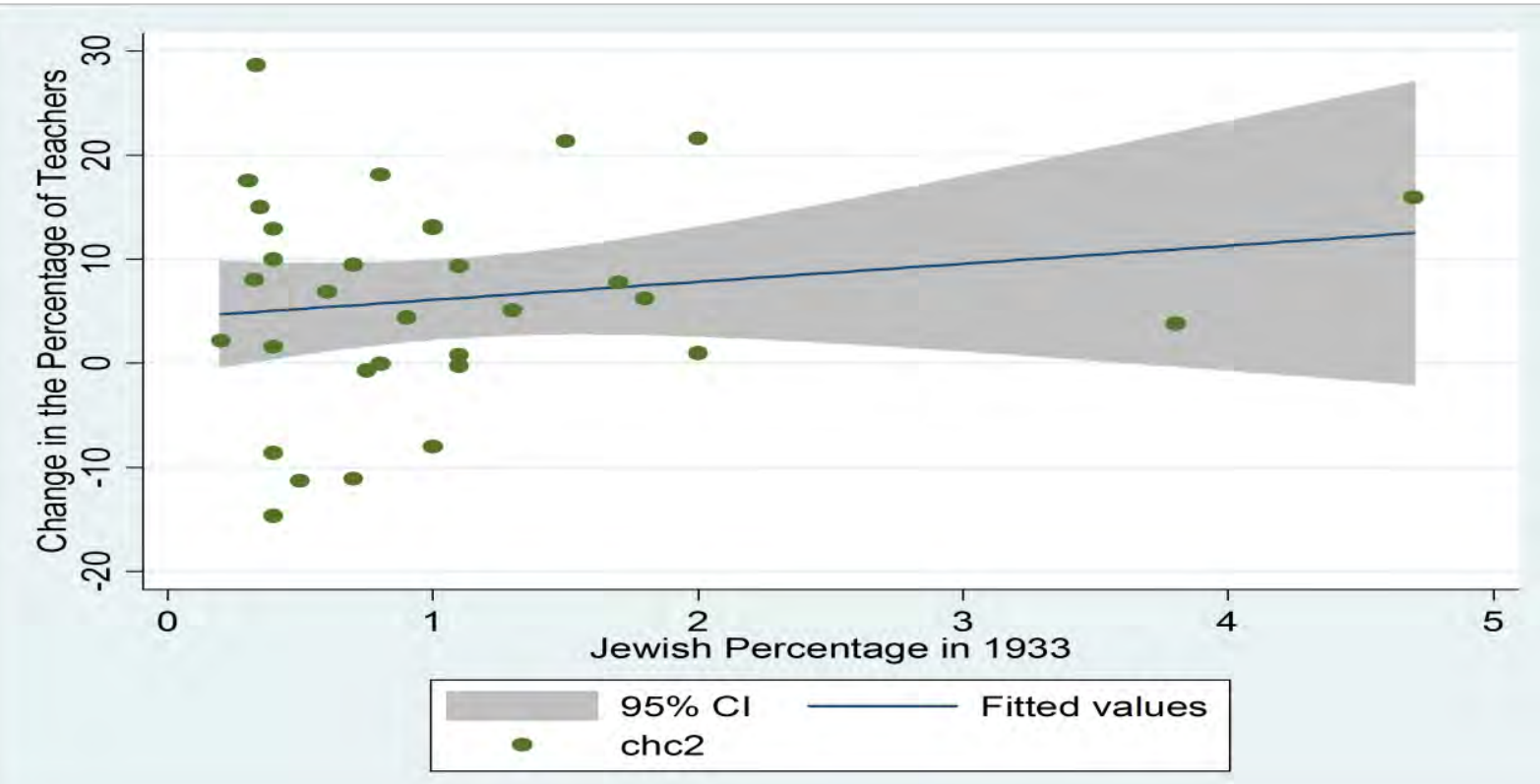

Source: Various years of German Statistical Yearbook. 
Figure 3: Map of Raumordnungsregionen (RORs or Cities) in Former West Germany

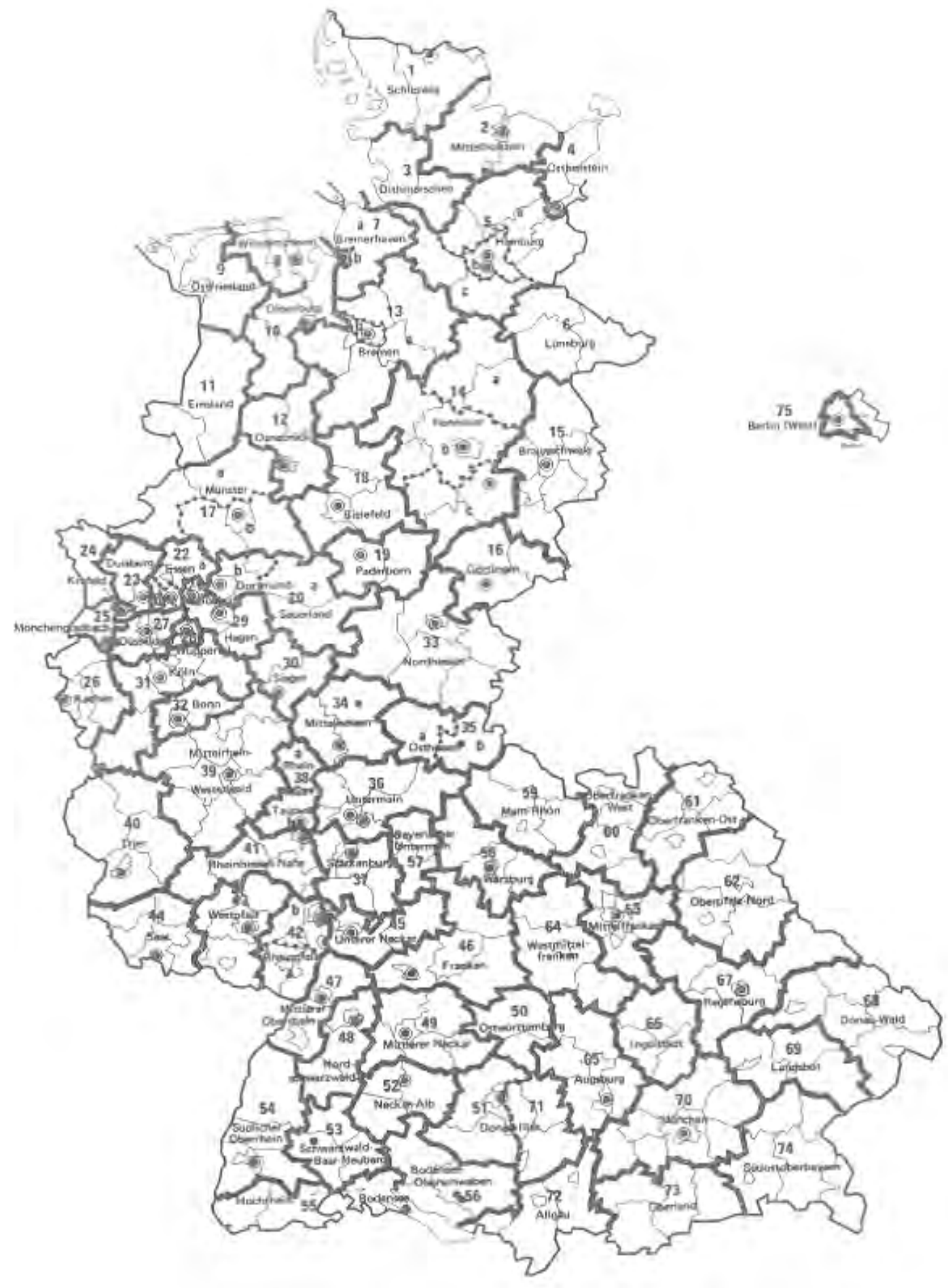

Source: Federal Office for Building and Regional Planning (Bundesamt für Bauwesen und Raumordnung, BBR). There are 75 regional policy regions (RORs) in former West Germany. 


\section{Figure 4: Estimated Effect of Holocaust on Full Distribution of Education}

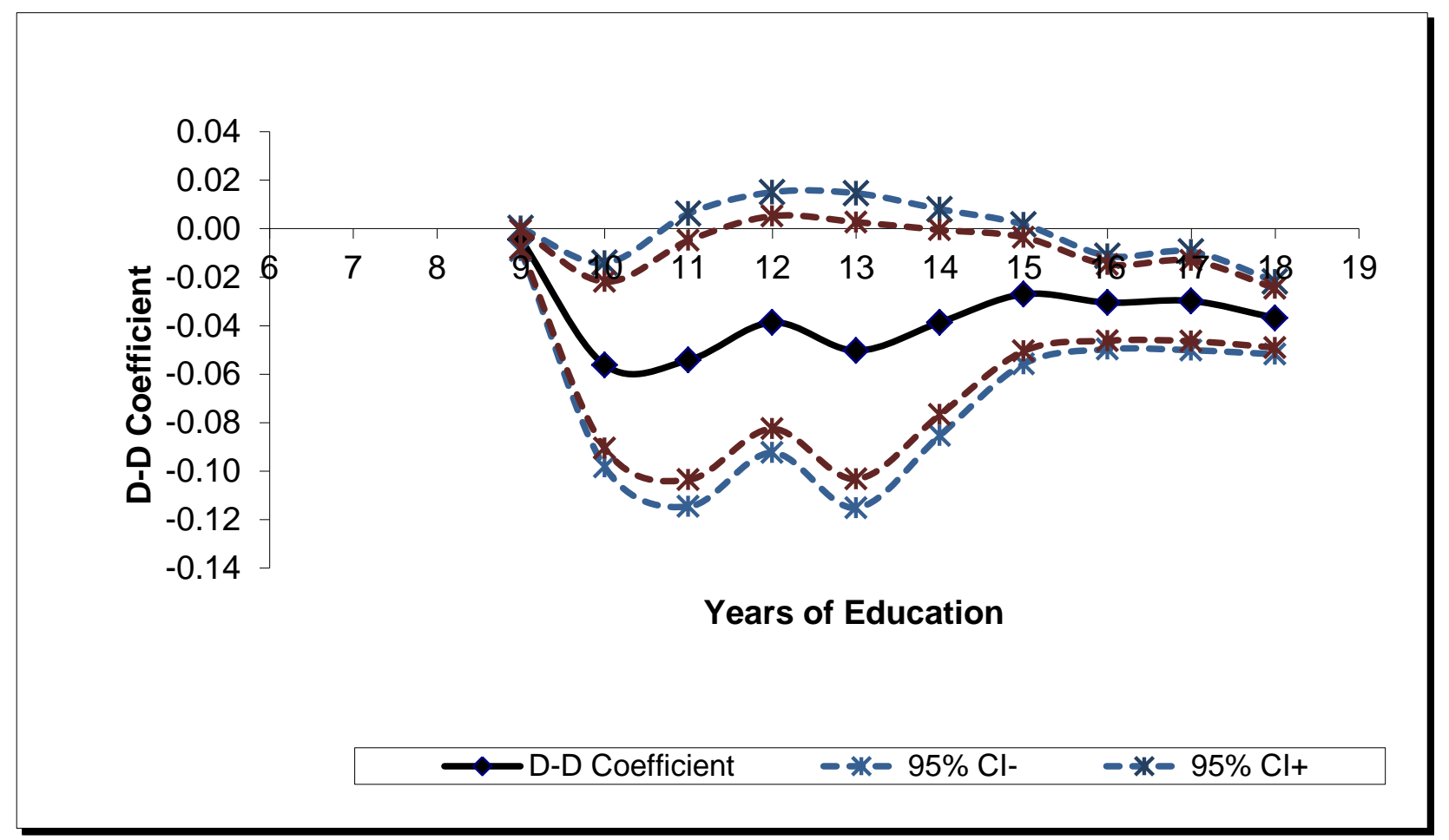

Notes: Each point in this figure is the difference-in-difference estimate from a separate regression where the outcome is a dummy variable that takes a value of 1 if an individual completed $m$ years of schooling or more and zero otherwise. In our sample, individuals complete between 7 and 18 years of schooling. 